\title{
A Datamining Based Decision Support System For Fruit Manufacturing
}

\author{
Figen Balo ${ }^{1}$, Lutfu S. Sua ${ }^{2}$, Ukbe Ucar ${ }^{1}$ \\ 1. Industrial Engineering Dept., Firat University, Elazlğ, Turkey \\ 2. Independed Researcher, Elazı̆̆, Turkey \\ Email: figenbalo@gmail.com; lutsua@gmail.com; uuucar@firat.edu.tr
}

Received: 24 April 2019; Accepted: 15 May 2019; Available online: 20 June 2019

\begin{abstract}
Agricultural activities provide one of the main sources of living in many regions of the world. Such products play significant roles for the survival of living organisms. Farmers all around the world work towards reaching their economic goals through agricultural activities. By doing this, they invest both their capital and time. In some occasions, such investments end up with serious losses and planted products either grow in low levels or do not grow at all. In this study, in order to avoid such situations and guide the investors intelligently, a decision support system based on decision tree is developed. Related parameters in accordance with the climatic and geographic characteristics of the region are determined within this proposed system. Then, appropriate types of fruits are proposed to the users as the outcome of the system based on these parameters. By doing this, producing more efficient and profitable products is aimed.
\end{abstract}

Keywords: Decision tree; Pomiculture; Classification of fruits; Decision support system.

\section{Introduction}

Agricultural activities provide one of the main sources of living for the human kind. Countries have developed employment fields in agriculture in accordance with aim of their economic survival through exporting the products they grow. Agriculture industry is a sector where millions of people make a living with. Significant investments are made with farmers and the governments every year and profit is expected accordingly. One of the critical points is coming up with the right policies. Wrong investment policies cause high levels of costs and result in infertile lands. A database is generated within the scope of this research considering a set of fruits and a decision support system is developed to help the investors in choosing the appropriate fruits to grow by linking them with the required geographic and climatic characteristics for growing these fruits. Although there are many studies in the literature about fruit growing but the amount of studies related to datamining or decision support system is quite limited. Jean Pennington and Fisher have classified the fruits and vegetables in terms of botanic family, color, part of the tree that it grows on, and total antioxidant in order to regulating feeding behavior and guiding it [1]. Lu et al. have developed a hybrid solution approach in classification of the fruits in their research. They combined PSO, ABC, and SLFN methods and stated that the proposed method outperforms existing methods at 85\% accuracy [2]. Zhang et al., developed a solution methodology in which they combined a forward feeding neural network method with a chaotic artificial bee algorithm to classify the fruits in reference with the scanned fruit pictures. They concluded that 1653 fruit pictures from 18 categories were classified with $89.1 \%$ accuracy [3]. Gill et al. considered fruits such as apple, grape, peach, orange, banana, and mango in their research by evaluating the studies in the literature classifying according to computer software techniques and reported their findings systematically [4]. Mercol et al. studied the problem of automatically classifying oranges by the use of datamining techniques and scanning process. Within the solution of the problem, they used six different methods including five different decision trees and one rule-based classification. They claimed that they obtained effective solutions with sufficient accuracy rate and low calculation cost [5]. Many studies related to decision trees exist in the literature and a selection of them is presented in Table 1.

The definition and the characteristics of the problem is provided in the second part of the study. The third part presents information regarding the solution methodology. The forth part provides information about the application study. The last part includes results obtained and future direction for the research.

\section{Problem definition}

Fruit growing has great significance for the World both from ecological and economical perspectives. Using land efficiently and survival of biological variety is only possible through increasing the green fields. Fruit growing is 
one of the most imprint sectors contributing to this aim. Moreover, considering that fruit growing is related to the fields such as pharmacy, cosmetics, food, and cleaning, the width of the field becomes more apparent.

Table 1. Studies on Decision trees

\begin{tabular}{|c|c|c|c|c|c|}
\hline Author & Year & Method & Author & Year & Method \\
\hline Balkaya et al. [6] & 2010 & $\begin{array}{l}\text { Main element analysis, } \\
\text { Cluster analysis }\end{array}$ & Sert et al., [13] & 2010 & $\begin{array}{l}\text { Image processing } \\
\text { technique }\end{array}$ \\
\hline Balci et al. [7] & 2016 & $\begin{array}{l}\text { Image processing } \\
\text { technique, Artificial } \\
\text { neural network }\end{array}$ & Sabzi et al., [14] & 2014 & $\begin{array}{l}\text { Image processing and } \\
\text { ANFIS }\end{array}$ \\
\hline $\begin{array}{l}\text { Kahya and } \\
\text { Arin[8] }\end{array}$ & 2014 & $\begin{array}{l}\text { Image processing } \\
\text { technique }\end{array}$ & $\begin{array}{l}\text { Durmus et al. } \\
\text { [15] }\end{array}$ & 2003 & \\
\hline $\begin{array}{l}\text { Basayigit and } \\
\text { Senol[9] }\end{array}$ & 2008 & $\begin{array}{l}\text { Geographic information } \\
\text { systems }\end{array}$ & $\begin{array}{l}\text { Wang et al., } \\
\text { [16] }\end{array}$ & 2015 & $\begin{array}{l}\text { WE, PCA, FNN, } \\
\text { FSCABC, BBO }\end{array}$ \\
\hline $\begin{array}{l}\text { Sabanci et al., } \\
{[10]}\end{array}$ & 2012 & $\begin{array}{l}\text { Image processing } \\
\text { technique, Artificial } \\
\text { neural network }\end{array}$ & Zhang et al., [3] & 2014 & $\begin{array}{l}\text { Forward artificial } \\
\text { neural network }\end{array}$ \\
\hline $\begin{array}{l}\text { Ozalp and } \\
\text { Ucar[11] }\end{array}$ & 2016 & $\begin{array}{l}\text { Artificial neural network } \\
\text { and K-Closest } \\
\text { neighborhood algorithm }\end{array}$ & Uçar et al., [17] & 2017 & $\begin{array}{l}\text { Classification and } \\
\text { Regression Trees }\end{array}$ \\
\hline $\begin{array}{l}\text { Kurtulmus et al., } \\
\text { [12] }\end{array}$ & 2013 & $\begin{array}{l}\text { Computer aided } \\
\text { techniques, Artificial } \\
\text { neural network, } \\
\text { Statistical classifiers }\end{array}$ & Yoo et al., [18] & 2016 & $\begin{array}{l}\text { ANN, CART and other } \\
\text { algorithms }\end{array}$ \\
\hline
\end{tabular}

Many countries import fruits due to their geographic and climatic characteristics and lack of water. The decision support system developed within this research aims to help determining the types of fruits that are feasible to produce domestically using scientific methods and invest accordingly, thus using the lands more efficiently. It is projected that such systems have the potential of guiding policy-makers come up with more appropriate employment policies and new employment opportunities and even increase export levels consequently.

Initially within the scope of the problem, some of the geographic and climatic factors having effect on the growth of a fruit are determined. Then, the properties of the fruits included in the research are associated with these parameters to generate a database. The resulting database is later used within the decision tree structure with the effort of developing an interactive decision support system. The fruits included in the study and the parameters effecting the growth of them are provided in Table 2 and 3, respectively.

It is estimated that more accurate classifications can be made possible by increasing the number of the fruits and the parameters.

Table 2. Fruits considered within this research

\begin{tabular}{llll}
\hline Fruit & Fruit & Fruit & Fruit \\
\hline Apple [19, 20] & Cherry [28] & Melon [37] & Erik [49] \\
Apricot [21] & Cranberry [29] & Kumquat [38,39] & Nar [50] \\
Pear [22] & Date palm [30] & Lemon [40] & Raspberry [51] \\
Banana [23] & Fig [31] & Mango [41] & Strawberry [52] \\
Blackberry [24] & Grapefruit [32] & Nectarine [42,43] & Mandarin [53] \\
Blueberry [25] & Grape [33] & Orange [44,45] & Watermelon [54] \\
Blackberry strawberry [26] & Guava [34,35] & Peach [46,47] & Chestnut [55] \\
Cantaloupe [27] & Kiwi [36] & Ananas [48] & Berry [56] \\
\hline
\end{tabular}

\section{Decision tree method}

Decision trees are ways of stating the learned tree structure within decision logic through the use of known sample data. In this structure, large amount of data is divided into small groups of data within the framework of certain rules. This is a widely used classification model due its easiness to use and evaluate as well as its ability to combine with other systems [57]. Decision trees have many different types including ID3, C4.5, Classification and regression trees (CRT), Automatic Chi-Square Matching, Chi-Square Automatic Interaction Detector (CHAID) [58]. CRT and C5.0 trees are used within this research when making classifications. 


\section{Application}

Parameters and methods provided in Part 2 and 3, respectively are associated using Clementine 12.0 program and a decision tree is obtained. Tree structure is expressed as in Table 4 due to the difficulty of showing the whole structure together. The screenshot of the program is provided in Figure 1. Decision trees obtained according to CRT and C5.0 methods are provided in Table 4 and 5, respectively. The branches stated in Table 4 can be summarized as follows: for instance, number 13 states that if the climate is half hot or hot, the land is clay-loamy, the best option is growing apricot.

Analyzing CR05 method, it becomes apparent that the decision tree is formed through climate and rain properties. For instance, number five states that in a region where the climate is soft, the land is not deep and rain amount is at middle level, growing blackberry, lemon, pomegranate, and nectarine would be more efficient.

It can be observed that some factors are not considered by both of the methods. Main reason of this is that the related solution methodology does not need these parameters when making the classification. Lack of data, having both quantitative and qualitative data together, and insufficient data for the related fruit can be mentioned as the main reasons.

Table 3. Factors considered within this research

\begin{tabular}{llllll}
\hline Climate Type & Soil Type & Water Req. & Humidity Req. & Avg. Temperature & Sub \\
\hline Mild & Pebble loamy & Very low & Very low & Very low & Very low \\
Cold mild & Loamy & Low & Low & Low & Low \\
Half hot & Sandy loamy & Middle & Middle & Middle & Middle \\
Dry & Clayey loamy & High & High & High & High \\
Tropical & Deep & Very high & Very high & Very high & Very high \\
Subtropical & Mineral & & & & \\
Desert & Acidic & & & & \\
& Aired & & & \\
& Sandy clayey & & & \\
& Sandy & & & \\
& Clayey & & & \\
& Organic & & & \\
& Strainer & & & \\
& Hot & & & \\
& Humic & & & \\
& Volcanic & & & \\
& Mild sandy & & & \\
\end{tabular}

Table 4. Decision tree obtained from CRT method

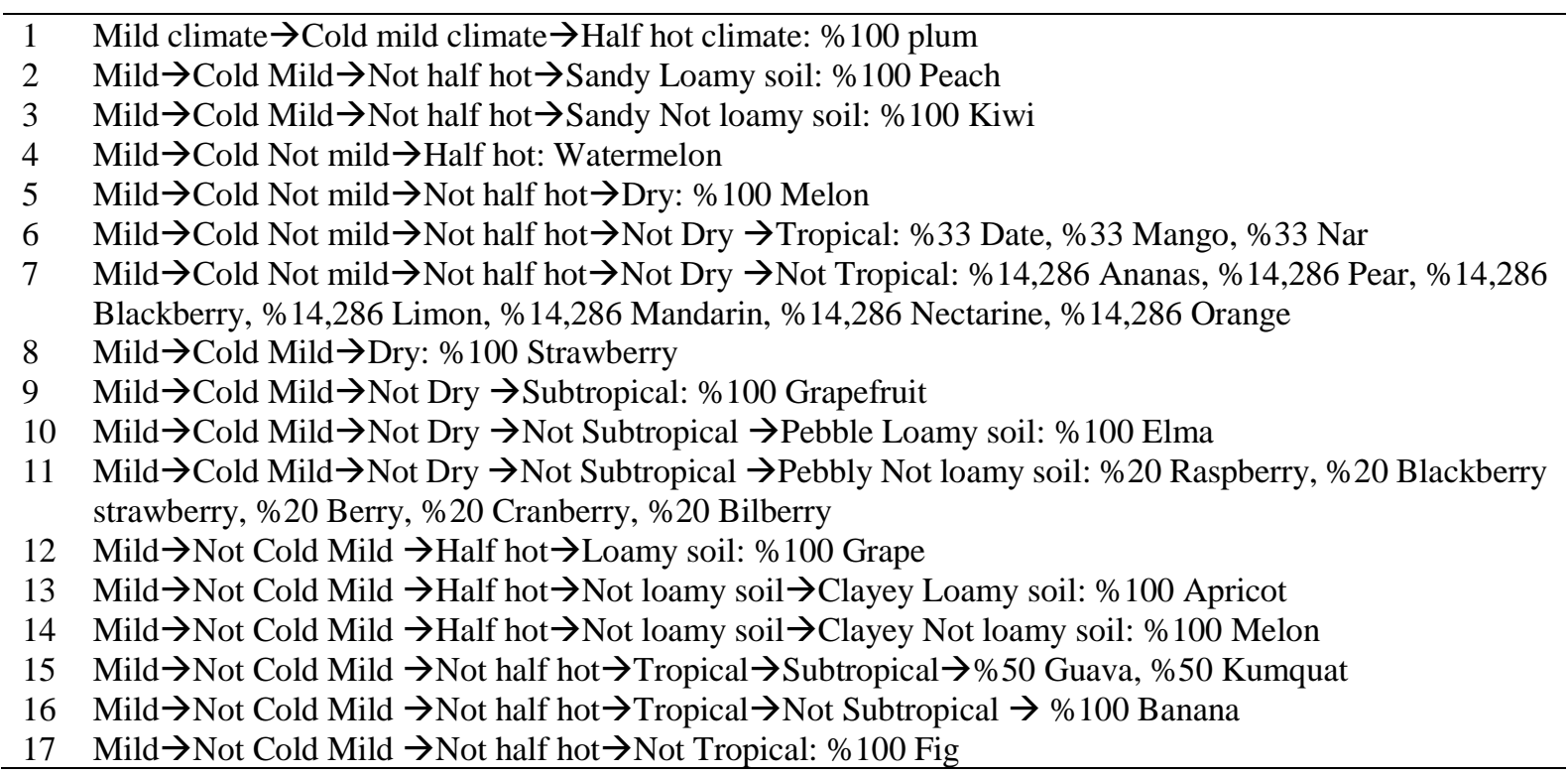




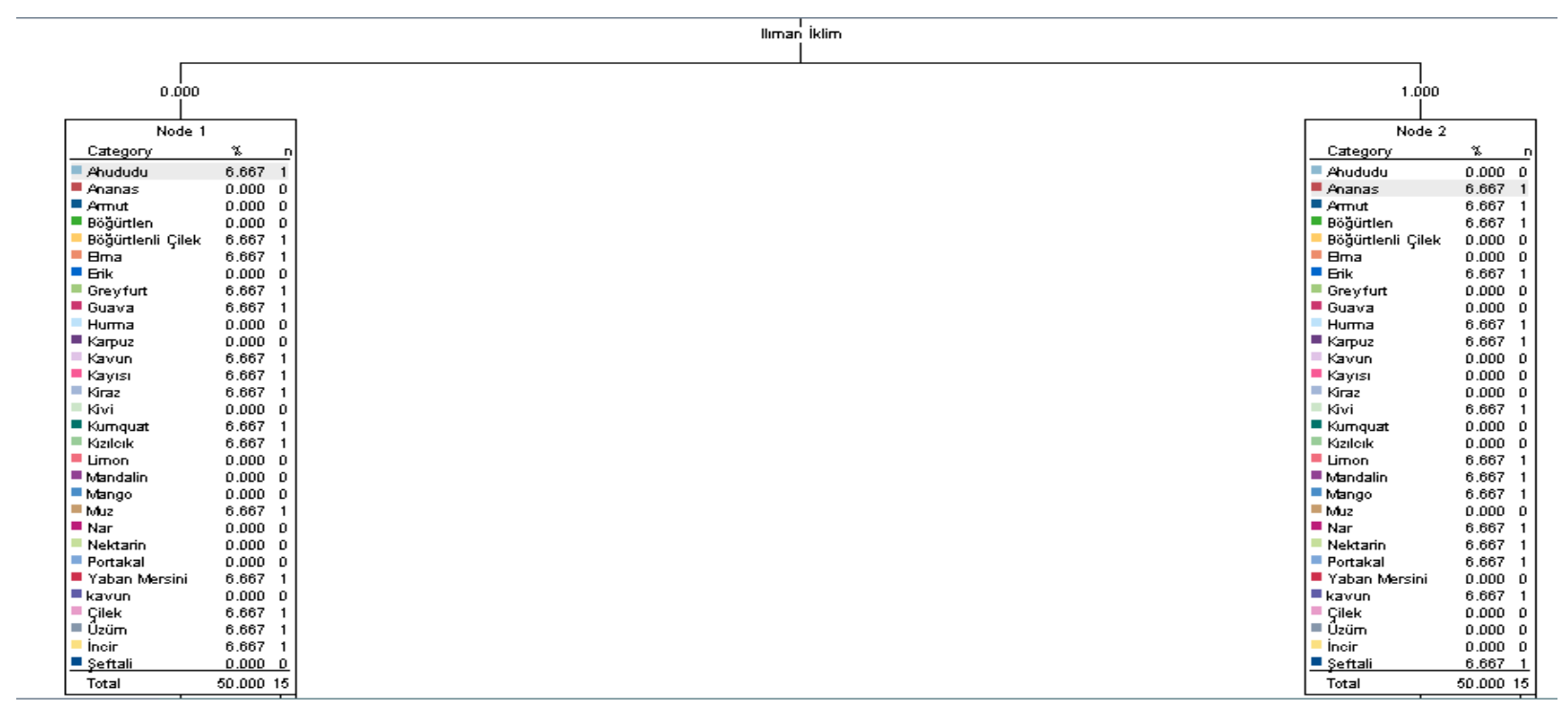

Figure 1. Decision tree structure obtained from Clementine 12.0 program

Table 5. Decision tree obtained from C5.0 method

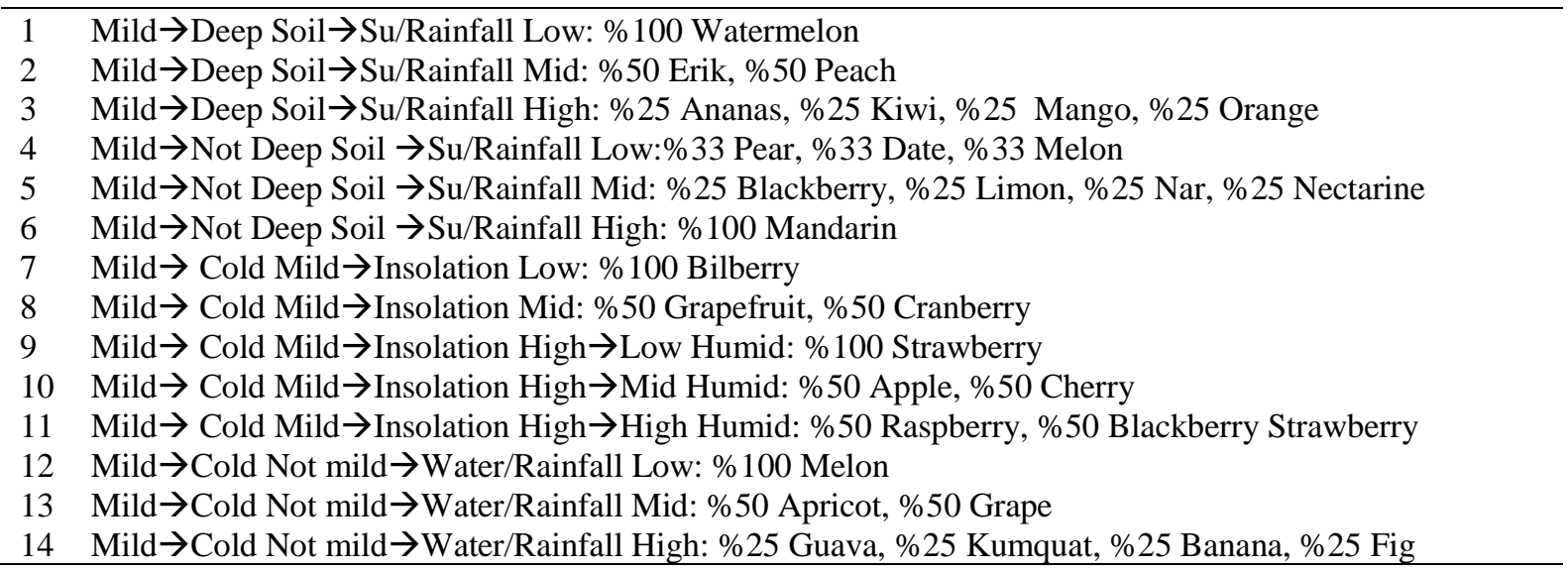

\section{Results and conclusions}

Agricultural activities are vital for all countries both in terms of economic value and survival of human kind. Agricultural sector has also strategic importance for efficient use of land and continuity of ecologic cycle. Fruit growing is one of the main agricultural activities. It is related to many industries since fruits are used in various fields such as medicine, chemistry, and cosmetics. Many investors every year invest significant amounts of capital in line with various agricultural policies. However, wrong investment policies cause infertility of the lands, thus resulting in great losses. In this research, a decision support system based on decision trees is developed in order to make feasible investment policies and grow more efficient fruits. Parameters having impact on the growth of fruits are determined initially and correlated with the fruits considered in the research to be able to develop the decision support system. By the use of this developed system, feasible fruits to be grown in any geographic region are provided for the users.

A new approach to the fruit growing is provided with this research, thus the number of parameters and fruits are kept limited. Parameters as well as the correlation between the parameters and the fruits need to be determined accurately, so that the relationship between the geographic properties and fruits can be developed. It is projected that better solutions can be obtained through more efficient solution methods and the addition of more fruits and different properties in future research.

\section{Acknowledgement}

This work is supported by the Tubitak-BIDEB 2211 PhD Scholarship Program. 


\section{References}

[1] Pennington JA, Fisher RA. Classification of fruits and vegetables. Journal of Food Composition and Analysis. 2009;22:S23-31.

[2] Lu S, Lu Z, Phillips P, Wang S, Wu J, Zhang Y. Fruit classification by HPA-SLFN. In: 2016 8th International Conference on Wireless Communications \& Signal Processing (WCSP). IEEE; 2016. p. 1-5.

[3] Zhang Y, Wang S, Ji G, Phillips P. Fruit classification using computer vision and feedforward neural network. Journal of Food Engineering. 2014;143:167-177.

[4] Gill J, Sandhu PS, Singh T. A review of automatic fruit classification using soft computing techniques. In: Int. Conf. Comput. Syst. Electron. Eng. 2014. p. 91-98.

[5] Mercol JP, Gambini MJ, Santos JM. Automatic classification of oranges using image processing and data mining techniques. In: XIV Congreso Argentino de Ciencias de la Computación. 2008.

[6] Balkaya A, Özbakır M, Karaağaç O. Evaluation of variation and fruit characterization of pumpkin (Cucurbitamoschata duch.) populations collected from Black Sea region. Journal of Agricultural Sciences. 2010;16(1):17-25. (in Turkish).

[7] Balcı M, Altun AA, Taşdemir Ş. Classification for napoleon type cherries by using image processing techniques. Selcuk-Technic Journal. 2016;15(3): 221-237. (in Turkish).

[8] Kahya E, Arın S. A Research on image color code analysis with fruit locating. Journal of Tekirdag Agricultural Faculty (JOTAF).2014;11(2): 110-118. (in Turkish).

[9] Başayiğit L, Şenol H. Determination of potential area to fruit growing by geographical information system and verification of remote sensing technology. SDU Journal of Faculty of Agriculture.2008; 9(1): 1-8. (in Turkish).

[10] Sabancı K, Aydın C, Ünlerşen MF. Determination of classification parameters of potatoes with the help of image processing and artificial neural network. Igdir University Journal of the Institute of Science and Technology.2012;2(10):59-62. (in Turkish).

[11] Uçar A, Özalp R. Low cost electronic nose design for detection and classification of fruit fragrances. In: Conference on Innovations in Intelligent Systems and Applications;2016. p. 75-79. (in Turkish).

[12] Kurtulmuş F, Vardar A, Kavdır İ. Detection of immature peach fruits in color images captured in orchard conditions using texture and shape features. Journal of Agricultural Machinery Science.2013;9(2):141-148. (in Turkish).

[13] Sert E, Taşkın D, Suçsuz N. Apple and peach classfication using image processing technics. Trakya Univ J Sci. 2010;11(2):82-88. (in Turkish).

[14] Sabzi S, Abbaspour-Gilandeh Y, Javadikia H, Havaskhan H. Automatic grading of Emperor apples based on image processing and ANFIS. Journal of Agricultural Sciences. 2015;21(3):326-336.

[15] Durmuş E, Yiğit A. The fruit producing regions of Turkey. Frrat University Journal of Social Science.2003; 13(2):23-54. (in Turkish).

[16] Wang S, Zhang Y, Ji G, Yang J, Wu J, Wei L. Fruit classification by wavelet-entropy and feedforward neural network trained by fitness-scaled chaotic $\mathrm{ABC}$ and biogeography-based optimization. Entropy. 2015;17(8):5711-5728.

[17] Uçar UU, Balo F, Eraslan G, Çetin B. A DSS study based on data mining for ideal animal breeding. Journal of Gaziosmanpasa Scientific Research. 6(Special Issue (ISMSIT2017)):133-141. (in Turkish).

[18] Yoo K, Shukla SK, Ahn JJ, Oh K, Park J. Decision tree-based data mining and rule induction for identifying hydrogeological parameters that influence groundwater pollution sensitivity. Journal of Cleaner Production. 2016; 122:277-286.

[19] https://www.turkeyarena.net/konu/elma-yetistirme-kosullari-elma-hangi-kosullarda-yetisir.50407/. [accessed 14 May 2019].

[20] http://www.bademlikoop.org.tr/tr/kayisi-yetistiriciligi/. [accessed 18 Feb. 2017].

[21] http://istanbul.tarim.gov.tr/Belgeler/KutuMenu/Brosurler/Meyvecilik/elma.pdf. [accessed 14 May 2019].

[22] http://arastirma.tarim.gov.tr/marem/Belgeler/YetistiricilikBilgileri/ArmutYetistiriciligi.pdf. [accessed 18 Feb. 2017].

[23] https://www.turkeyarena.net/konu/Banana-yetistirme-kosullari.37761/. [accessed 14 May 2019].

[24] http://arastirma.tarim.gov.tr/marem/Belgeler/YetistiricilikBilgileri/Raspberry-BortlenYetistiriciligi.pdf. [accessed 18 Feb. 2017].

[25] http://www.bursaplant.com/Yaban-Mersini-Yetistiriciligi,DP-22.html. [accessed 14 May 2019].

[26]http://hbogm.meb.gov.tr/modulerprogramlar/kursprogramlari/bahcecilik/moduller/bogurtlen_yetistiriciligi.pdf. [accessed 14 May 2019].

[27] http://istanbul.tarim.gov.tr/Belgeler/KutuMenu/Brosurler/Meyvecilik/kavun.pdf. [accessed 14 May 2019 ].

[28] http://www.megep.meb.gov.tr/mte_program_modul/moduller_pdf/KirazYetistiriciligi.pdf. [accessed 18 Feb. 2017].

[29] http://nasilkolay.com/kizilcik-nerede-yetisir. [accessed 14 May 2019]. 
[30] https://tr.wikipedia.org/wiki/Hurma. [accessed 14 May 2019].

[31] http://www.tarimkutuphanesi.com/INCIR_YETISTIRICILIGI_00300.html. [accessed 14 May 2019].

[32] http://www.megep.meb.gov.tr/mte_program_modul/moduller_pdf/GrapefruitYetistiriciligi.pdf. [accessed 18 Feb. 2017].

[33] http://www.sifalibitkileriniz.com/bagbahce/uzum-yetistiriciligi.html. [accessed 14 May 2019].

[34] http://www.tropikalmeyveler.com/guava.htm. [accessed 18 Feb. 2017].

[35] http://batem.gov.tr/yayinlar/bilimsel_makaleler/meyvecilik/alparslan/subtropik.pdf. [accessed 14 May 2019].

[36] http://www.tarimkutuphanesi.com/KIVI_YETISTIRICILIGI_00301.html. [accessed 14 May 2019].

[37] http://www.tarimkutuphanesi.com/KAVUN_YETISTIRICILIGI_00030.html. [accessed 14 May 2019].

[38] http://arastirma.tarim.gov.tr/alata/Belgeler/Digerbelgeler/KamkatYetistiriciligiHocagil.pdf. [accessed 18 Feb. 2017].

[39] http://azbitki.com/kamkat-kumquat-fortunella-japonica. [accessed 14 May 2019].

[40] http://hbogm.meb.gov.tr/modulerprogramlar/kursprogramlari/bahcecilik/moduller/limon_yetistiriciligi.pdf. [accessed 14 May 2019].

[41] http://nasilkolay.com/mango-nerede-yetisir. [accessed 14 May 2019].

[42] http://www.eyasamrehberi.com/photo/meyva_agaclari/nektarin.htm\#. [accessed 18 Feb. 2017].

[43] http://www.nkfu.com/nektarin-agaci-nasil-yetistirilir/. [accessed 14 May 2019].

[44] https://www.turkeyarena.net/konu/pMidkal-hangi-iklimde-yetisir-pMidkal-iklimkosullari.36098/. [accessed 14 May 2019].

[45] http://nasilkolay.com/pMidkal-nerede-yetisir. [accessed 18 Feb. 2017].

[46] http://www.seftali.info/seftali-yetistiriciligi.php. [accessed 14 May 2019].

[47] http://www.bahcenet.com/seftali-yetistiriciligi-prunus-persica-stokes.html. [accessed 18 Feb. 2017].

[48] http://www.tarimmarketi.com/Yet_ananas.aspx. [accessed 18 Feb. 2017].

[49] http://www.agacnet.com/erik-agaci/erik-hangi-iklimde-yetisir.html. [accessed 14 May 2019].

[50] http://ziraattan.blogspot.com.tr/2008/11/nar-yetitiricilii.html. [accessed 14 May 2019].

[51] http://www.tarimkutuphanesi.com/RASPBERRY_YETISTIRICILIGI_00297.html. [accessed 14 May 2019].

[52] http://www.tarimkutuphanesi.com/CILEK_YETISTIRICILIGI_-_1_00296.html. [accessed 14 May 2019].

[53] http://biriz.biz/rize/Mandarina.htm. [accessed 18 Feb. 2017].

[54] http://www.tarimkutuphanesi.com/KARPUZ_YETISTIRICILIGI_00029.html. [accessed 14 May 2019].

[55] http://www.kestane.gen.tr/kestane-agaci-nerelerde-yetisir.html. [accessed 14 May 2019].

[56] http://nasilkolay.com/dut-agaci-nerede-yetisir. [accessed 14 May 2019].

[57] Albayrak AS, Yılmaz ŞK. Data mining: decision tree algorithms and an application on ISE data. SDU The Journal of Faculty of Economics and Administrative Sciences.2009;14(1): 31-52. (in Turkish).

[58] Koyuncugil AS, Özgülbaş N. Strengths and weaknesses of smes which is trade in IMKB: CHAID decision tree application. Dokuz Eylul University The Journal of Faculty of Economics and Administrative Sciences. 2013; 23(1): 1-21. (in Turkish).

(c) 2019 by the author(s). This work is licensed under a Creative Commons Attribution 4.0 International License (http://creativecommons.org/licenses/by/4.0/). Authors retain copyright of their work, with first publication rights granted to Tech Reviews Ltd. 